\title{
REVIEW
}

\section{The meningococcus tamed?}

\author{
A J Pollard, E R Moxon
}

Arch Dis Child 2002;87:13-17

Serogroup B Neisseria meningitidis is a frequent cause of invasive meningococcal disease, yet there are no effective vaccines suitable for routine immunisation. Limited efficacy has been shown with meningococcal outer membrane vacccines in children 4 years and older. Here we review the status of current research and consider new approaches to development of meningococcal serogroup $B$ vaccines.

I 2002, Neisseria meningitidis will remain one of the leading infectious causes of death in childhood in many industrialised countries, including the United Kingdom, and a cause of devastating epidemics in non-industrialised nations. Some 500000 cases of endemic meningococcal infection are thought to occur annually worldwide, ${ }^{1}$ with the greatest burden of disease in Africa and Asia and many more cases reported when there are epidemics. Several new vaccine initiatives provide the possibility of a major reduction in the global burden of this disease during the coming decade.

\section{MENINGOCOCCAL DISEASE AND VACCINATION}

Five serogroups of meningococci, A, B, C, Y, and W135, defined by the biochemistry of their polysaccharide capsule, are responsible for almost all meningococcal disease, although the overall proportions of cases caused by each serogroup vary widely around the globe. Serogroup A meningococci are the cause of cyclic epidemic meningitis in Africa $^{2}$ and Asia, ${ }^{3}$ and occasional outbreaks have been associated with population movements and overcrowding in other regions over the past half century. ${ }^{4}$ In industrialised nations serogroup B meningococci cause $30-70 \%$ of cases of sporadic meningococcal disease $\mathrm{e}^{5-7}$ and have been responsible for pockets of persistently increased rates of disease. ${ }^{8-10}$ Serogroup C meningococci are particularly associated with small outbreaks of disease among teenagers and young adults and sporadic disease in individuals of other ages. ${ }^{6}$ Serogroup Y disease is uncommon in the United Kingdom, but accounts for up to 30\% of cases in the United States ${ }^{6}$; rates of Y disease may also be on the increase in parts of Canada. ${ }^{7}$ Occasional sporadic disease caused by W135 meningococci had been largely ignored until a recent large outbreak among pilgrims to the Hajj in 2000. ${ }^{11}$ Although the epidemiological characteristics of disease caused by each serogroup are intriguingly different, the clinical features of invasive disease are mostly indistinguishable.
Although it is likely that antibiotics and specialist intensive care can significantly reduce the mortality from meningococcal septicaemia, ${ }^{12}$ it is clear that timely, universal delivery of such care cannot be guaranteed for all children, particularly in the context of this fulminant disease that kills in hours. Widespread control of meningococcal disease is an important goal in paediatric practice and immunisation seems the obvious solution.

MenC, the protein-polysaccharide conjugate vaccine that was introduced into the UK primary infant schedule in November 1999, has already had a major impact on disease caused by serogroup $\mathrm{C}$ meningococci in childhood in this country. ${ }^{13}$ The vaccine has also been licensed in other countries around Europe, ${ }^{14}$ and in Canada. ${ }^{7}$ Furthermore, development of combination A, C, Y, and W135 protein-polysaccharide conjugate vaccines is underway, and there is an expectation that these vaccines will be available within a few years, and will provide effective protection against these serogroups from infancy; combination with pneumococcal protein-polysaccharide conjugate vaccines is planned. ${ }^{15}$ There is also optimism, boosted by the announcement of significant funding from the Bill and Melinda Gates Foundation in July 2001, that further development of a serogroup A/C conjugate vaccine under the direction of the Global Alliance for Vaccines and Immunization (GAVI) will halt the cycle of epidemic disease in Africa. ${ }^{16}$

Optimism that global control of disease caused by A, C, Y, and W135 meningococci is within reach must be tempered by the absence of an imminent solution to the problem of serogroup B disease in children. The highest attack rate of meningococcal disease is in children under 5 years of age; at this age, $50 \%$ of disease is caused by serogroup B meningococci in the USA (1992-1996), ${ }^{6} 39 \%$ in Canada (1985-2000), ${ }^{7}$ and more than $65 \%$ in the UK (1999-2000). ${ }^{5}$

Vaccines against the non-B serogroups (A, Y, and W135) of meningococci that contain the capsular polysaccharide of the organism conjugated to a protein carrier are currently under development, using the same technology as was used in the development of Haemophilus influenzae type b (Hib) vaccines. ${ }^{17}$ MenC, the new serogroup C protein-polysaccharide conjugate vaccine, is already in routine use in parts of Europe and Canada. MenC is highly immunogenic from infancy, ${ }^{18}$ and it is expected that similar immunogenicity and protection will be afforded by A, Y, and W135 conjugate vaccines.

Abbreviations: Hib, Haemophilus influenzae type b; LPS, lipopolysaccharide; OMP, outer membrane protein; OMV, outer membrane vesicle 
Table 1 Results of serogroup B meningococcal vaccines in phase II/III trials

\begin{tabular}{|c|c|c|c|c|}
\hline Vaccine developer & Vaccine constituents & Immunogenicity & Efficacy & Reference \\
\hline $\begin{array}{l}\text { Connaught Laboratories } \\
\text { Inc., USA }\end{array}$ & $\begin{array}{l}\text { Aluminium hydroxide adsorbed } \\
\text { serogroup B OMP (B:4:P1.3) + C } \\
\text { polysaccharide }\end{array}$ & $\begin{array}{l}\text { Induction of bactericidal antibody } \\
\text { but poor responses in young children } \\
\text { (<4 years) }\end{array}$ & $\begin{array}{l}70 \% \text { efficacy in older children } \\
\text { in Chile. No protection }<4 \\
\text { years of age }\end{array}$ & 26 \\
\hline Finlay Institute, Cuba & $\begin{array}{l}\text { Aluminium hydroxide adsorbed } \\
\text { OMV from CU385 }(\mathrm{B}: 4: \mathrm{Pl}, 15) \text { plus } \\
\text { C polysaccharide }\end{array}$ & $\begin{array}{l}\text { Variable immunogenicity. Good } \\
\text { response in Cuban teenagers and } \\
\text { children in Chile against the } \\
\text { homologous strain. Poor } \\
\text { immunogenicity in Brazilian children } \\
\text { and lcelandic teenagers and limited } \\
\text { cross immunogenicity to non-vaccine } \\
\text { meningococci }\end{array}$ & $\begin{array}{l}83 \% \text { efficacy in Cuban } \\
\text { teenagers; } 70 \% \text { efficacy in } \\
\text { children }>4 \text { years in Brazil; } \\
\text { non-protective in children }<4 \\
\text { years of age in Brazil }\end{array}$ & $24,32-34,54$ \\
\hline NIPH, Norway & $\begin{array}{l}\text { Aluminium hydroxide adsorbed } \\
\text { OMV from } 44 / 76(\mathrm{~B}: 15: \mathrm{P} 1.7,16)\end{array}$ & $\begin{array}{l}\text { Immunogenic in Norwegian } \\
\text { teenagers, Chilean infants and } \\
\text { children, and Icelandic teenagers, } \\
\text { but limited cross protection to } \\
\text { non-vaccine serotypes }\end{array}$ & $57 \%$ in Norwegian teenagers & $29,33,55$ \\
\hline RIVM, Netherlands & $\begin{array}{l}\text { Aluminium phosphate adsorbed } \\
\text { combination of } 2 \text { different } \mathrm{OMV} \text { s } \\
\text { expressing } 6 \text { PorA proteins } \\
\text { (P1.7, 16; P1.5c, } 10 ; \mathrm{P} 1.5,2 ; \\
\left.\mathrm{P} 1.7^{\mathrm{h}}, 4 ; \mathrm{P} 1.19,15 ; \mathrm{P} 1.12,13\right)\end{array}$ & $\begin{array}{l}\text { Immunogenic in British infants, Dutch } \\
\text { toddlers, and Dutch school children } \\
\text { but the } 6 \text { antigens showed unequal } \\
\text { immunogenicity after } 3 \text { doses } \\
\text { (16-100\% response) }\end{array}$ & Not available & 30,35 \\
\hline RIVM, Netherlands & $\begin{array}{l}\text { Aluminium hydroxide or aluminium } \\
\text { phosphate adsorbed OMVs } \\
\text { expressing one PorA protein } \\
\left(\mathrm{P} 1.7^{\mathrm{h}}, 4\right)\end{array}$ & $\begin{array}{l}\text { Immunogenic in Dutch toddlers } \\
\text { (55-80\% response). Response } \\
\text { dependent on adjuvant used }\end{array}$ & Not available & 56 \\
\hline
\end{tabular}

Meningococci are classically classified by: (1) serogroup (the biochemical nature of the capsular polysaccharide: A, B, C, Y, W135); (2) serotype (the antigenic type of a surface protein called PorB); and (3) serosubtype (the antigenic type of a surface protein called PorA). Hence strain B:15:P1.7, 16 is serogroup $B$, subtype 15 , sersubtype $P 1.7,16$.

However, the polysaccharide capsule of serogroup B meningococci is a homopolymer of sialic acid, which is chemically identical to polysaccharides found in human tissues during development. ${ }^{19}$ Hence, the B capsule is seen by the immune system as a self antigen and is thus poorly immunogenic, even after conjugation to a protein carrier. ${ }^{20}$ Therefore, the "simple" strategy of polysaccharide-protein conjugation (described above for protection against non-serogroup B meningococci) cannot easily be translated to serogroup B meningococci and various alternative strategies are in active development.

\section{STRATEGIES FOR SEROGROUP B MENINGOCOCCAL VACCINE DEVELOPMENT}

A number of different strategies for prevention of serogroup B disease are considered below. Evaluation of the potential utility of each vaccine candidate is difficult because of the lack of an accepted laboratory surrogate of protection. There is no defined level of circulating antibody to serogroup B meningococci that is known to relate to protection against the disease, but some indirect evidence suggests that a certain titre of bactericidal antibody (antibody that can kill meningococci in the laboratory in the presence of complement) might be correlated with protection at the population level. ${ }^{21}$ However, the lack of an established laboratory correlate of protection has hampered the development of serogroup B vaccines.

\section{Polysaccharide vaccines}

While the lack of immunogenicity of the serogroup B sialic acid capsule is a major problem in development of a capsule based $B$ vaccine, research efforts in this area continue because of the attractiveness of a vaccine antigen that is, by definition, shared across this group of meningococci. Chemical modification of the polysaccharide ( $\mathrm{N}$-propionylation), in an attempt to induce immunogenic epitopes, has resulted in development of a protein-polysaccharide conjugate vaccine that elicits functional (bactericidal) antibody in both mice and nonhuman primates. ${ }^{22}$ Some of the antibodies elicited have activity against polysialic acid and therefore have the potential to be autoreactive in humans, although no deleterious effects have been noted in early human trials (personal communication, P Fusco, Baxter, 2001). However, other antibodies that arise after immunisation with a conjugate $\mathrm{N}$-propionylated serogroup B polysaccharide vaccine do not cross react with human tissues and might therefore be used in the development of molecular mimetics of the non-autoreactive epitopes, and result in the production of a safe serogroup B vaccine. ${ }^{23}$

\section{Outer membrane protein vaccines}

The difficulties in production of an effective serogroup B polysaccharide vaccine have led to investigation of other bacterial surface structures as vaccine constituents. Beneath the polysaccharide capsule, meningococci are surrounded by an outer membrane, rich in protein, lipoprotein, and lipopolysaccharide.

Since the 1970s the outer membrane proteins (OMPs) of serogroup B $N$ meningitidis have been extensively studied as potential vaccine constituents. However, the exposed regions of these structures are almost all antigenically highly variable among different serogroup B isolates, such that a vaccine containing a protein from a single organism is unlikely to provide cross protection to all other serogroup B bacteria. Furthermore, the antigenic regions of many of these protein structures appear to evolve rapidly within bacterial populations, perhaps as a result of pressure from acquired immunity in human populations so that a vaccine may become ineffective against the evolved strain. Despite these problems, several vaccine candidates have reached trials and one is in routine use in Central and South America, ${ }^{24}$ though none of these vaccines has proven effectiveness in young children, those most affected by serogroup B disease.

Early OMP vaccines consisted of insoluble aggregates of outer membrane proteins and, although immunogenic in animals, were poorly immunogenic in humans. ${ }^{25}$ Another OMP vaccine containing purified OMPs non-covalently complexed to meningococcal C polysaccharide was tested in a trial in Chile and provided some protection in older children and young adults $(70 \%)$, but was poorly protective in children less than 5 years of age. ${ }^{26}$ In order to improve immunogenicity by presenting the proteins in a more natural conformation, several developers have produced OMP vaccines in solution that contain OMPs in spheres of bacterial outer membrane, known as outer membrane vesicles (OMVs). ${ }^{24-30}$ These OMV vaccines have now 
Table 2 Vaccine candidates under consideration for a serogroup B meningococcal vaccine

\begin{tabular}{|c|c|c|c|}
\hline Protein & Function & Vaccine potential & Reference \\
\hline Adhesion penetration protein (App) & Autotransporter protein & Antibodies present following human infection & 57 \\
\hline Ferric binding protein (FbpA) & Iron binding & Antibodies could block iron uptake & 58 \\
\hline FetA (FrpB) & Ferric enterobactin receptor & $\begin{array}{l}\text { Possible vaccine candidate but antigenic } \\
\text { heterogeneity }\end{array}$ & 59,60 \\
\hline GNA33 & Transglycosylase & Immunogenic in animals & 41 \\
\hline Lactoferrin binding protein (LbpA) & Lactoferrin binding & Antibodies present following human infection & 61 \\
\hline Lipopolysaccharide (LPS) & Endotoxin & $\begin{array}{l}\text { Bactericidal antibodies induced following } \\
\text { infection and OMV vaccination. Antibodies } \\
\text { have bactericidal activity against a range of } \\
\text { meningococcal isolates }\end{array}$ & $49-51,53$ \\
\hline Neiserrial surface protein A (NspA) & Unknown & Immunogenic and "protective" in animals & 62,63 \\
\hline $\begin{array}{l}\text { Opacity associated protein }(\mathrm{OpA} ; \\
\text { class } 5)\end{array}$ & Adhesion/invasion & $\begin{array}{l}\text { Potential for antibodies induced by } \\
\text { immunisation to block adhesion/invasion }\end{array}$ & 64 \\
\hline OpcA (Opc; class 5c) & Invasion/adhesion & $\begin{array}{l}\text { Present in NIPH OMV vaccine and a target for } \\
\text { vaccine induced bactericidal antibodies }\end{array}$ & 64 \\
\hline Pilin & Adhesion & $\begin{array}{l}\text { Potential for antibodies induced by } \\
\text { immunisation to block adhesion }\end{array}$ & 65 \\
\hline PorA (class 1 protein) & Cation porin & $\begin{array}{l}\text { Major protein component of RIVM, NIPH, and } \\
\text { Finlay Institute OMV vaccines and is the target } \\
\text { for vaccine induced bactericidal antibodies. No } \\
\text { protection shown in young children with these } \\
\text { vaccines }\end{array}$ & 66,67 \\
\hline PorB (class $2 / 3$ protein) & Anion porin & $\begin{array}{l}\text { Immunogenic in humans after infection and } \\
\text { OMV vaccination }\end{array}$ & 68 \\
\hline $\begin{array}{l}\text { Reduction modifiable protein (Rmp; } \\
\text { class } 4 \text { ) }\end{array}$ & Unknown & $\begin{array}{l}\text { May cause induction of "blocking" antibodies } \\
\text { and therefore not a desirable vaccine } \\
\text { constituent }\end{array}$ & 69 \\
\hline Transferrin binding protein A (TbpA) & Acquisition of iron from transferrin & Immunogenic and "protective" in animals & 70 \\
\hline Transferrin binding protein $B(\mathrm{Tbp} B)$ & Acquisition of iron from transferrin & $\begin{array}{l}\text { Immunogenic and "protective" in animals. Early } \\
\text { human trials show unsatisfactory } \\
\text { immunogenicity }\end{array}$ & $38,71,72$ \\
\hline
\end{tabular}

been evaluated in large scale trials ( see table 1), and shown to be immunogenic and partially protective in older children. ${ }^{24} 2629$ Unfortunately, again, there is no evidence of protection against serogroup B disease in any of these studies in children under 4 years of age..$^{26}{ }^{31} 32$ Furthermore, bactericidal antibody appears to be largely confined to the serogroup B meningococcal "type" included in the vaccine..$^{33} 34$

The major protein immunogen in these OMV vaccines is a porin protein named PorA, which is antigenically variable. In an attempt to overcome this variability and provide cross strain protection, a hexavalent OMV vaccine was produced containing six different PorA proteins (see table 1). Phase II trials in various age groups have shown variable immunogenicity to each PorA type. ${ }^{30}{ }^{35}$ Unfortunately, minor mutations in the genes encoding this protein are common and result in evasion of complement mediated killing of the organism, reducing the likelihood of success with this approach. ${ }^{36}$

The observation that some protection and induction of bactericidal antibody directed against the vaccine strain is induced with monovalent OMV vaccines suggests that these vaccines may be of use in outbreaks of serogroup B disease caused by a single "type" of bacteria. In New Zealand, rates of meningococcal disease 4-20 times higher than other industrialised countries have been observed for the past decade, ${ }^{8}$ with a majority of cases caused by closely related serogroup B meningococci. In July 2001, the Ministry of Health in New Zealand announced plans for further development of a monovalent OMV vaccine with Chiron Corporation in conjunction with National Institute for Public Health (NIPH), Norway in the hope of halting serogroup B disease. ${ }^{37}$

\section{Other outer membrane protein vaccine candidates}

The antigenic variability of the major OMP, PorA, the disappointing efficacy of OMV vaccines, and concerns over safety and immunogenicity of B polysaccharide vaccines have directed research to other surface exposed OMPs. Prior to evalauation in human trials, the ideal candidate(s) should be immunogenic (induction of serum bactericidal antibody following immunisation), protective in animal models, and have limited antigenic variability. Table 2 lists a number of possible vaccine candidates, but there is likely to be a problem with antigenic variability for a number of these. Nevertheless, some of these vaccine candidates have shown promise in preclinical studies. Of these, only TbpB has been evaluated in preliminary human trials, but immunogenicity was disappointing with the vaccination formulation used..$^{38}$

The recent availability of two meningococcal genome sequences ${ }^{39}{ }^{40}$ has provided a new resource for the search for vaccine candidates. ${ }^{41}$ Using computer software to scan the meningococcal genome, Pizza and colleagues ${ }^{41}$ have identified 570 open reading frames (sequences of DNA), which encode proteins that are likely to be surface exposed or secreted by meningococci. Following cloning into an $E$ coli expression system, animal immunogenicity studies and selection of the most promising candidates, seven proteins were chosen for further study. These proteins were all shown to be surface exposed; five of these novel proteins were found to be widely expressed among pathogenic Neisseria (with $>99 \%$ sequence homology), and two were able to induce bactericidal antibody in mice (GNA33 and GNA1946). Several of these proteins have been used in animal studies and found to be less immunogenic than OMVs, ${ }^{42}$ though combinations of proteins appear to be more immunogenic than single proteins. ${ }^{43}$ Further development of vaccines using this strategy is anticipated. ${ }^{44}$

A similar approach using genome mining has been described by Poolman and Berthet ${ }^{44 a}$ using sequence from serogroup B strain ATCC13090 to produce recombinant vaccine candidates in $E$ coli. Preclinical evaluation of these proteins led to the identification of 10 promising vaccine candidates. Upregulated expression of some of these OMPs has been achieved by either gene delivery (replacement of a dispensable gene with the vaccine candidate by homologous recombination) or promoter replacement (delivery of a strong promoter upstream of the gene of interest), prior to production of candiate OMV vaccines containing the upregulated OMPs. ${ }^{44 a}$ 
In another molecular approach, genetic manipulation of meningococci was recently used to identify genes that are involved in pathogenesis of the organism in an animal model. ${ }^{45}$ Some of the proteins encoded by these genes are likely bacterial surface structures and could be evaluated for vaccine potential.

\section{Whole cell and exotoxin vaccines}

One approach to the problem of heterogeneity of surface structures is to develop vaccines that contain a wide range of surface antigens rather than a single cross protective antigen. Indeed, the history of meningococcal vaccine development began almost a century ago with trials of killed whole cell vaccines, but it seems that there was limited efficacy and a high incidence of adverse reactions to these vaccines. ${ }^{46}$ Trials of exotoxin vaccines in the 1930s also showed some promise but were not pursued. ${ }^{46}$ More recently, nasal immunisation with a live commensal organism such as $N$ lactamica $^{47}$ or with a live attenuated $N$ meningitidis vaccine ${ }^{48}$ have been considered. There is currently no evidence that these approaches will be successful in humans and it is unlikely that live attenuated $N$ meningitidis vaccines would ever receive regulatory authority approval, but the concept of presentation of multiple antigens in a single vaccine is likely to be pursued.

\section{Lipopolysaccharide}

Lipopolysaccharide (LPS; endotoxin), a major component of the meningococcal outer membrane, is believed to be the bacterial factor responsible for the dramatic clinical presentation of meningococcal disease through stimulation of widespread inflammatory cytokine production. Like the polysaccharide capsule, LPS is highly conserved among invasive isolates, making this an attractive vaccine candidate for serogroup B meningococci and more broadly across the serogroups. Bactericidal anti-LPS antibodies are present in convalescent human serum $^{49}$ and after immunisation with an LPS containing OMV vaccine in non-human primates. ${ }^{50}$ Moreover, a single murine antibody directed at the inner core of LPS appears to have bactericidal activity against $70 \%$ of meningococci tested (including isolates from serogroup $\mathrm{A}$ and $\mathrm{B}$ ), ${ }^{51}$ and also enhances opsonophagocytic activity of human phagocytes. ${ }^{52} \mathrm{~A}$ protein-lipopolysaccharide conjugate inner core LPS vaccine has been produced that induces bactericidal antibody in animals and has activity against an array of meningococcal isolates. $^{53}$

\section{CONCLUSION}

In the next few years, it is likely that effective multivalent protein-polysaccharide conjugate meningococcal vaccines will become available for the control of disease caused by serogroup A, C, Y, and W135 meningococci, either alone or in combination with pneumococcal conjugate vaccines.

Outer membrane vesicle (OMV) vaccines for serogroup B meningococci are already in use for endemic disease in parts of Central and South America, but these vaccines appear to offer no protection for young children and provide limited cross protection to non-vaccine serogroup B meningococci. Further large trials of monovalent OMV vaccines are expected imminently in New Zealand and offer the possibility of control of hyperendemic clonal serogroup B disease.

Perhaps inspired by the availability of genomic data, efforts to produce an effective vaccine for protection against serogroup B meningococci are today more intense than ever before, and several novel candidates are already in preclinical or early clinical trials. However, serogroup B meningococci must not be underestimated. The success of these bacteria as colonisers of the human nasopharynx probably lies in their ability to vary their immunogenic surface structures and evade immunologic attack, whether natural or vaccine induced. Vaccines that are directed at a single variable surface structure are unlikely to be successful, but this problem might be overcome by use of multicomponent protein vaccines. Highly conserved structures such as the capsular polysaccharide (despite the developmental problems noted above), inner core lipopolysaccharide, or conserved proteins that have limited variability are the most attractive vaccine candidates, and it is likely that several of these candidates will be advancing through clinical trials within the next five years.

The meningococcus has not yet been tamed but the momentum in vaccine development today is far greater than ever before, with involvement from many research groups, government institutions, and at least five vaccine manufacturers. There is reason for optimism that control of endemic meningococcal disease through infant immunisation against all five serogroups may be within reach.

\section{Authors' affiliations}

A J Pollard, E R Moxon, Oxford Vaccine Group, Department of Paediatrics, University of Oxford, John Radcliffe Hospital, Oxford OX3 9DU, UK

\section{REFERENCES}

1 Tikhomirov E, Santamaria M, Esteves K. Meningococcal disease: public health burden and control. World Health Stat Q 1997:50:170-7.

2 Lapeyssonnie L. La meningite cerebro-spinale en Afrique. Bull WHO 1963;28:3-114

3 Wang JF, Caugant DA, Li X, et al. Clonal and antigenic analysis of serogroup A Neisseria meningitidis with particular reference to epidemiological features of epidemic meningitis in the People's Republic of China. Infect Immun 1992;60:5267-82.

4 Achtman M. Global epidemiology of meningococcal disease. In: Cartwright K, ed. Meningococcal disease. Chichester: John Wiley and Sons, 1995: 159-75.

5 Communicable Disease Surveillance Centre and the Meningococcal Reference Unit. Invasive meningococcal infections, England and Wales, by age and serogroup. http://www.phls.co.uk/ facts/Mening/N\%20Mening/meni-Quarters.htm (accessed 2001).

6 Rosenstein NE, Perkins BA, Stephens DS, et al. The changing epidemiology of meningococcal disease in the United States, 1992-1996. J Infect Dis 1999;180:1894-901.

7 Pollard AJ, National Committee on Immunization (NACI). Statement on recommended use of meningococcal vaccines. Can Commun Dis Rev. In press.

8 Baker M, McNicholas A, Garrett N, et al. Household crowding a major risk factor for epidemic meningococcal disease in Auckland children. Pediatr Infect Dis J 2000; 19:983-90.

9 Diermayer M, Hedberg K, Hoesly F, et al. Epidemic serogroup B meningococcal disease in Oregon: the evolving epidemiology of the ET-5 strain. JAMA 1999:281:1493-7.

10 Stuart JM, Cartwright KA, Jones DM, et al. An outbreak of meningococcal disease in Stonehouse: planning and execution of a large-scale survey. Epidemiol Infect 1987;99:579-89.

11 Centers for Disease Control and Prevention. Update: Assessment of risk for meningococcal disease associated with the Haii 2001. Morb Mortal Wkly Rep 2001;50:221-2

12 Levin M, Galassini R, de Munter C, et al. Improved survival in children admitted to intensive care with meningococcal disease. In: 2nd Annual Spring Meeting of the Royal College of Paediatrics and Child Health University of York. Royal College of Paediatrics and Child Health, 1998.

13 Ramsay ME, Andrews N, Kaczmarski EB, et al. Efficacy of meningococcal serogroup $C$ conjugate vaccine in teenagers and toddlers in England. Lancet 2001;357:195-6.

14 Cartwright K, Noah N, Peltola H. Meningococcal disease in Europe: epidemiology, mortality and prevention with conjugate vaccines. Vaccine $2001 ; 19: 4347-56$

15 Morley SL, Pollard AJ. Vaccine prevention of meningococcal disease, coming soon? Vaccine. In press.

16 World Health Organisation. The meningitis vaccine project. http://www.who.int/vaccines/intermediate/meningococcus.htm (accessed 2001).

17 Heath PT. Haemophilus influenzae type b conjugate vaccines: a review of efficacy data. Pediatr Infect Dis J 1998;17:S1 17-22.

18 Maclennan J. Meningococcal group C conjugate vaccines. Arch Dis Child 2001;84:383-6.

19 Finne J, Bitter-Suermann D, Goridis C, et al. An lgG monoclonal antibody to group $B$ meningococci cross-reacts with developmentally regulated polysialic acid units of glycoproteins in neural and extraneural tissues. J Immunol 1987;138:4402-7.

20 Bartoloni A, Norelli F, Ceccarini C, et al. Immunogenicity of meningococcal $B$ polysaccharide conjugated to tetanus toxoid or CRM197 via adipic acid dihydrazide. Vaccine 1995;13:463-70.

21 Goldschneider I, Gotschlich EC, Artenstein MS. Human immunity to the meningococcus. I. The role of humoral antibodies. J Exp Med $1969 ; 129: 1307-26$. 
22 Fusco PC, Michon F, Tai JY, et al. Preclinical evaluation of a novel group $\mathrm{B}$ meningococcal conjugate vaccine that elicits bactericidal activity in both mice and nonhuman primates. J Infect Dis 1997;175:364-72.

23 Granoff DM, Bartoloni A, Ricci S, et al. Bactericidal monoclonal antibodies that define unique meningococcal B polysaccharide epitopes that do not cross-react with human polysialic acid. J Immunol 1998; 160:5028-36

24 Sierra GV, Campa HC, Varcacel NM, et al. Vaccine against group B Neisseria meningitidis: protection trial and mass vaccination results in Cuba. NIPH Ann 1991;14:195-210.

25 Zollinger WD, Mandrell RE, Altieri $\mathrm{P}$, et al. Safety and immunogenicity of a Neisseria meningitidis type 2 protein vaccine in animals and humans. J Infect Dis 1978;137:728-39.

26 Boslego J, García J, Cruz C, et al. Efficacy, safety, and immunogenicity of a meningococcal group $B(15: P 1.3)$ outer membrane protein vaccine in lquique, Chile. Chilean National Committee for Meningococcal Disease. Vaccine 1995;13:821-9.

27 Zollinger WD, Mandrell RE, Griffiss JM, et al. Complex of meningococcal group $B$ polysaccharide and type 2 outer membrane protein immunogenic in man. J Clin Invest 1979:63:836-48.

28 Frasch CE, Zahradnik JM, Wang LY, et al. Antibody response of adults to an aluminum hydroxide-adsorbed Neisseria meningitidis serotype $2 \mathrm{~b}$ protein-group B polysaccharide vaccine. J Infect Dis 1988;158:710-18.

29 Bjune G, Høiby EA, Grønnesby JK, et al. Effect of outer membrane vesicle vaccine against group $B$ meningococcal disease in Norway. Lancet 1991;338:1093-6.

30 Cartwright K, Morris R, Rümke $\mathrm{H}$, et al. Immunogenicity and reactogenicity in UK infants of a novel meningococcal vesicle vaccine containing multiple class 1 (PorA) outer membrane proteins. Vaccine 1999;17:2612-19.

31 de Moraes JC, Perkins BA, Camargo MC, et al. Protective efficacy of a serogroup B meningococcal vaccine in Sao Paulo, Brazil. Lancet 1992;340: 1074-8

32 Noronha CP, Struchiner CJ, Halloran ME. Assessment of the direct effectiveness of $\mathrm{BC}$ meningococcal vaccine in Rio de Janeiro, Brazil: a case-control study. Int J Epidemiol 1995;24:1050-7.

33 Perkins BA, Jonsdottir K, Briem H, et al. Immunogenicity of two efficacious outer membrane protein-based serogroup $B$ meningococcal vaccines among young adults in Iceland. J Infect Dis 1998;177:683-91.

34 Tappero JW, Lagos R, Ballesteros AM, et al. Immunogenicity of 2 serogroup $B$ outer-membrane protein meningococcal vaccines: a randomized controlled trial in Chile. JAMA 1999;281:1520-7.

35 de Kleijn ED, de Groot R, Labadie J, et al. Immunogenicity and safety of a hexavalent meningococcal outer-membrane vesicle vaccine in children of 2-3 and 7-8 years of age. Vaccine 2000;18:1456-66.

36 Rosenqvist E, Høiby EA, Wedege E, et al. A new variant of serosubtype $\mathrm{P} 1.16$ in Neisseria meningitidis from Norway, associated with increased resistance to bactericidal antibodies induced by a serogroup $B$ outer membrane protein vaccine. Microb Pathog 1993;15:197-205.

37 New Zealand Ministry of Health. Development of meningococcal vaccine to begin. http://www.moh.gov.nz/moh.nsf/wpg_Index/ News+and+Issues-Index (accessed 2001).

38 Danve B, Lissolo L, Guinet F, et al. Safety and immunogenicity of a Neisseria meningitidisgroup $B$ transferrin binding protein vaccine in adults. In: Eleventh International pathogenic Neisseria conference, Nice. EDK, Paris, 1998

39 Tettelin H, Saunders NJ, Heidelberg J, et al. Complete genome sequence of Neisseria meningitidis serogroup B strain MC58. Science 2000;287: 1809-15

40 Parkhill J, Achtman M, James KD, et al. Complete DNA sequence of a serogroup A strain of Neisseria meningitidis Z2491. Nature 2000;404:502-6.

41 Pizza M, Scarlato V, Masignani V, et al. Identification of vaccine candidates against serogroup $B$ meningococcus by whole-genome sequencing. Science 2000;287:1816-20.

42 Giuliani MM, Pizza M, Santini L, et al. Immunogenicity and bactericida activity of conserved N. meningitidis serogroup B antigens. In: Twelfth International Pathogenic Neisseria Conference, Galveston. Health Care Communications Inc., 2000.

43 Santini L, Brunelli B, Luzzi E, et al. Immunogenicity of combinations of $\mathrm{N}$. meningitidis serogroup $\mathrm{B}$ antigens. In: Twelfth International Pathogenic Neisseria Conference, Galveston. Health Care Communications Inc., 2000

44 Rappuoli R. Reverse vaccinology, a genome-based approach to vaccine development. Vaccine 2001;19:2688-91.

44a Poolman J, Berthet FX. Alternative vaccine strategies to prevent serogroup B meningococcal diseases. Vaccine 2001;20(suppl 1):S24-5.

45 Sun YH, Bakshi S, Chalmers R, et al. Functional genomics of Neisseria meningitidis pathogenesis. Nat Med 2000;6:1269-73.

46 Feavers IM. Meningococcal vaccines and vaccine developments. In: Pollard AJ, Maiden MCJ, eds. Meningococcal vaccines. Totowa, NJ: Humana Press Inc., 2001:1-22.

47 Gorringe AR, Bracegirdle P, Oliver K, et al. Neisseria lactamica as a vaccine against meningococcal disease. In: Abstracts of the 39th Interscience Conference on Antimicrobial Agents and Chemotherapy. San Francisco: American Society for Microbiology, 1999.
48 Tang C, Moxon R, Levine MM. For discussion: live attenuated vaccines for group B meningococcus. Vaccine 1999;17:114-17

49 Griffiss JM, Brandt BL, Broud DD, et al. Immune response of infants and children to disseminated infections with Neisseria meningitidis. J Infect Dis 1984:150:71-9.

50 Zollinger WD, Moran EE, Devi SJ, et al. Bactericidal antibody responses of juvenile rhesus monkeys immunized with group B Neisseria meningitidis capsular polysaccharide-protein conjugate vaccines. Infect Immun 1997; 65: 1053-60.

51 Plested JS, Makepeace K, Jennings MP, et al. Conservation and accessibility of an inner core lipopolysaccharide epitope of Neisseria meningitidis. Infect Immun 1999;67:5417-26.

52 Plested JS, Ferry BL, Coull PA, et al. Functional opsonic activity of human serum antibodies to inner core lipopolysaccharide (gale) of serogroup b meningococci measured by flow cytometry. Infect Immun $2001 ; 69: 3203-13$

53 Arumugham R, Fortuna-Nevin M, Mountzouros K, et al. Development of lipooligosaccharide-protein conjugate vaccines against group $B$ Neisseria meningitidis. In: The fifth conference of the International Endotoxin Society, Santa Fe, 1998.

54 Milagres LG, Ramos SR, Sacchi CT, et al. Immune response of Brazilian children to a Neisseria meningitidis serogroup B outer membrane protein vaccine: comparison with efficacy. Infect Immun 1994;62:4419-24.

55 Tappero JW, Lagos R, Ballesteros AM, et al. Immunogenicity of 2 serogroup $B$ outer-membrane protein meningococcal vaccines: a randomized controlled trial in Chile. JAMA 1999:281:1520-7.

56 de Kleijn ED, de Groot R, Lafeber $A B$, et al. Immunogenicity and safety of monovalent $\mathrm{pl} .7(\mathrm{~h}), 4$ meningococcal outer membrane vesicle vaccine in toddlers: comparison of two vaccination schedules and two vaccine formulations. Vaccine 2000;19:1 141-8.

57 Abdel-Hadi H, Wooldridge K, Robinson K, et al. Investigation of the potential of App as a vaccine candidate. In: Twelth International Neisseria conference, Galveston, Texas. HCC Inc., 2000

58 Gomez JA, Criado MT, Ferreiros CM. Bactericidal activity of antibodies elicited against the Neisseria meningitidis $37-k D a$ ferric binding protein (FbpA) with different adjuvants. FEMS Immunol Med Microbiol 1998;20:79-86.

59 Carson SD, Klebba PE, Newton SM, et al. Ferric enterobactin binding and utilization by Neisseria gonorrhoeae. J Bacteriol 1999;181:2895901.

60 Ala'Aldeen DA, Davies HA, Borriello SP. Vaccine potential of meningococcal FrpB: studies on surface exposure and functional attributes of common epitopes. Vaccine 1994;12:535-41.

61 Johnson AS, Gorringe AR, Mackinnon FG, et al. Analysis of the human $\mathrm{lg}$ isotype response to lactoferrin binding protein A from Neisseria meningitidis. FEMS Immunol Med Microbiol 1999;25:349-54.

62 Martin D, Cadieux N, Hamel J, et al. Highly conserved Neisseria meningitidis surface protein confers protection against experimental infection. J Exp Med 1997; 185: 1 173-83.

63 Cadieux N, Plante M, Rioux CR, et al. Bactericidal and cross-protective activities of a monoclonal antibody directed against Neisseria meningitidis NspA outer membrane protein. Infect Immun 1999;67:4955-9

64 Virii M, Makepeace K, Ferguson DJ, et al. Meningococcal Opa and Opc proteins: their role in colonization and invasion of human epithelial and endothelial cells. Mol Microbiol 1993;10:499-510.

65 Stephens DS, McGee ZA. Attachment of Neisseria meningitidis to human mucosal surfaces: influence of pili and type of receptor cell. $J$ Infect Dis 1981;143:525-32.

66 Claassen I, Meylis J, van der Ley P, et al. Production, characterization and control of a Neisseria meningitidis hexavalent class 1 outer membrane protein containing vesicle vaccine. Vaccine 1996;14:1001-8.

67 Fredriksen JH, Rosenqvist E, Wedege E, et al. Production, characterization and control of MenB-vaccine "Folkehelsa": an outer membrane vesicle vaccine against group B meningococcal disease. NIPH Ann 1991; 14:67-80

68 Rosenqvist E, Tjade T, Frøholm LO, et al. An ELISA study of the antibody response after vaccination with a combined meningococcal group $B$ polysaccharide and serotype 2 outer membrane protein vaccine. NIPH Ann 1983;6:139-49

69 Munkley A, Tinsley CR, Virji M, et al. Blocking of bactericidal killing of Neisseria meningitidis by antibodies directed against class 4 outer membrane protein. Microb Pathog 1991;11:447-52

70 West D, Reddin K, Matheson M, et al. Recombinant Neisseria meningitidis transferrin binding protein $A$ protects against experimental meningococcal infection. Infect Immun 2001;69:1561-7.

71 Rokbi B, Renauld-Mongenie G, Mignon M, et al. Allelic diversity of the two transferrin binding protein $B$ gene isotypes among a collection of Neisseria meningitidis strains representative of serogroup $B$ disease: implication for the composition of a recombinant TbpB-based vaccine. Infect Immun 2000;68:4938-47.

72 Danve B, Lissolo L, Mignon M, et al. Transferrin-binding proteins isolated from Neisseria meningitidis elicit protective and bactericidal antibodies in laboratory animals. Vaccine 1993;11:1214-20. 